\title{
Ripening pattern of guava cv. Pedro Sato
}

\author{
Padrão de amadurecimento de goiaba cv. Pedro Sato
}

\author{
José Renato de ABREU ${ }^{1 *}$, Custódio Donizete dos SANTOS ${ }^{1}$, Celeste Maria Patto de ABREU ${ }^{1}$, \\ Ana Carla Marques PINHEIRO' ${ }^{1}$, Angelita Duarte CORRÊA ${ }^{1}$
}

\begin{abstract}
Guava is a fruit with high respiration rates and a very short shelf life. Since information on its respiration pattern is contradictory, the objective was to study the changes occurring in the fruit during ripening and to relate them to the respiration behavior of this fruit. Guavas were picked at the half-ripe stage and stored for 8 days at $22 \pm 1{ }^{\circ} \mathrm{C}$ and $78 \pm 1 \%$ relative humidity. The analyses conducted were: peel and pulp coloration, firmness, total soluble solids (TSS), total titratable acidity (TTA), and ethylene production. According to the results, it was verified that the parameters analyzed apparently do not coincide and are ethylene-independent. There was an accentuated ethylene production during ripening, starting from the $4^{\text {th }}$ day. The ethylene synthesis continued increasing up to the $8^{\text {th }}$ day, when the fruits were already decomposing. It was observed that the firmness decreased sharply in the first three days of ripening, and the skin and pulp color changed during ripening. The TSS, total soluble solids, and the TTA, total titratable acidity, practically did not change during the ripening, even with the increased ethylene production. It can be concluded that guava is a fruit that presents characteristics of climacteric and non-climacteric fruits.

Keywords: Psidium guajav; ripening; ethylene.
\end{abstract}

\section{Resumo}

A goiaba apresenta altas taxas de respiração e uma vida útil muito curta, e como as informações sobre o padrão respiratório são contraditórias, objetivou-se estudar mudanças ocorridas no fruto durante o amadurecimento e relacioná-las ao comportamento respiratório desses frutos. Foram colhidas goiabas no estádio "de vez" e armazenadas por 8 dias à temperatura ambiente $\left(22 \pm 1{ }^{\circ} \mathrm{C}\right.$ e umidade relativa de $\left.78 \pm 1 \%\right)$. As análises realizadas foram: coloração da casca e polpa, firmeza, sólidos solúveis totais (SST), acidez total titulável (ATT) e produção de etileno. Pelos resultados, verificou-se que todas as variáveis analisadas aparentemente não coincidem e independem da síntese de etileno. A produção de etileno durante o amadurecimento teve aumento acentuado a partir do $4^{\circ}$ dia. Até o $8^{\circ}$ dia, com os frutos já em fase de decomposição, a síntese do etileno continuava aumentando. Observou-se que a firmeza diminuiu acentuadamente nos três primeiros dias de amadurecimento e a cor da casca e da polpa alteraram com o amadurecimento. Os SST e a ATT dos frutos praticamente não variaram durante o amadurecimento, mesmo com o aumento da produção de etileno. Conclui-se que a goiaba é um fruto que apresenta características de frutos climatéricos e também de frutos não climatéricos.

Palavras-chave: Psidium guajava; amadurecimento; etileno.

\section{Introduction}

Among the traditional fruits, guava (Psidium guajava L.) stands out for its nutritional value as an excellent vitamin $\mathrm{C}$ source and for its high acceptance for "in natura" consumption or in the processed form.

Brazil is the largest world producer of red guavas and the export is about $700 \mathrm{t}$ of guava derived products (MENDONÇA et al., 2007). In 2006, the production was around $328.255 \mathrm{t}$ in an area of 14.982 ha. This production is concentrated mainly in the Southeast and Northeast regions, and the states of São Paulo and Pernambuco are the largest producers (INSTITUTO..., 2008).

Guava is a fruit with high respiration rates and a very short postharvest life, which limits transportation and storage period. This is an aspect that hinders or even prohibits the shipment of these fruits to distant consumer markets (XISTO et al., 2004).
Several postharvest treatments have been tested in guavas and, although many are efficient in delaying ripening and preserving the fruit quality, some interfere in the sensory characteristics of the fruit and others extend the shelf life in an economically insignificant way, or they leave chemical residues (OLIVEIRA et al., 2006).

Refrigerated storage is the main postharvest treatment to control fruit ripening and deterioration since it regulates the rate of the physiological and biochemical processes associated. However, as with most tropical and subtropical fruits, their sensitivity to the cold can cause the development of physiological disorders, depending on the temperature and storage period.

The knowledge of guava quality characteristics for the in natura consumption is related to its physical attributes (appearance, size, shape, coloration, and firmness) and chemical

${ }^{1}$ Departamento de Química, Universidade Federal de Lavras - UFLA, CP 3037, CEP 37200-000, Lavras, MG, Brazil, e-mail: jrenatoabreu@yahoo.com.br ${ }^{*}$ Corresponding author 
composition (TSS, TTA), responsible for the flavor. Those characteristics are highly relevant factors, even being influenced by the variety, maturation stage, cultivation area climatic conditions, and cultivation practices because they are used as a reference for the acceptability of the fruit in the national and international market.

The ripening of the fruits corresponds to a series of physiological, biochemical, and structural factors and changes such as changes in color, firmness, production of volatile compounds, accumulation of sugars, organic acid oxidation, and decrease of alkaloids (RHODES, 1980). Among all of these factors, firmness is the most important attribute since besides defining the quality of the fruit for "in natura"consumption and for processing, it also contributes to postharvest life of the fruit by offering protection during transportation and resistance to microorganism attack. The decrease in firmness during ripening has been attributed to modifications and degradation of the components of the cell wall (CARVALHO et al., 2001a), as well as to the decrease of the fruit integrity (CHITARRA; CHITARRA, 2005).

Fruits are usually divided in two groups according to their respiration pattern: climateric and non-climateric. In climateric fruits, such as banana and tomato, the onset of ripening is associated to an increase in the respiratory activity and ethylene biosynthesis. Non-climateric fruits do not exhibit an increase in ethylene production and respiratory activity during ripening, and they do not have the capacity to ripen postharvest and their flavor does not improve.

The classification of fruits as climateric or non-climateric is essential to define the harvest time as well as handling and storage techniques which can be used to prolong the postharvest life (ARCHBOLD; POMPER, 2003).

Available information on the respiration pattern of guavas (Psidium guajava L.) is contradictory. Since it presents some non-climateric fruit characteristics, some authors consider guava as a fruit belonging to that group (BIALE; BARCUS; 1970; CHITARRA; CHITARRA, 2005), while other authors Akamine and Goo (1979), Brown and Wills (1983), Oliveira (1996), Mercado-Silva et al. (1998), Lima, Durigan and Tostes (1998), Azzolini (2005), Mendonça et al. (2007) classify guava as climateric fruit for presenting an increase in the respiration rate and high postharvest ethylene production (climateric peak), which results in its high perishability under ambient conditions.

As mentioned before, the available information on the respiration pattern of guavas is contradictory; therefore, the objective of this study was to study the physical and chemical changes occurring in the fruit during ripening and to relate them to ethylene production.

\section{Materials and methods}

\subsection{Origin and collection of the fruit}

The guavas (Psidium guajava L.) of the cv. Pedro Sato were picked manually early in the morning, at the half-ripe stage (light green coloration) from a commercial orchard located in the municipal district of Lavras, Minas Gerais, altitude $845 \mathrm{~m}$, latitude $21.15^{\circ}$ South, longitude $45.22^{\circ}$ West. The fruits were placed in previously sterilized polyethylene boxes and transported to the Biochemistry Laboratory of the Department of Chemistry (DQI) of the Federal University of Lavras/MG.

The fruits were selected, washed under running water, and immersed in a $1 \%$ sodium hypochlorite solution at $20^{\circ} \mathrm{C}$ for 5 minutes for disinfection. After drying, the fruits were numbered, stored in a shelf in the laboratory, and maintained at a temperature and relative humidity of $22 \pm 1{ }^{\circ} \mathrm{C}$ and $78 \pm 1 \%$, respectively for a period of 8 days.

\subsection{Experimental design}

The experimental design used was completely random (CRD), with 8 treatments (1-8 days of ripening). The experimental sample was composed of 3 fruits, and the experiment consisted of 4 repetitions for each treatment. The results were submitted to the variance analysis using the SANEST software (ZONTA; MACHADO, 1991). Regression analyses were conducted, and the polynomial models were selected observing the significance of the $\mathrm{F}$ test for each model and their respective determination coefficients.

\subsection{Physical analyses}

\section{Coloration}

The peel and pulp color was determined using a CR 300 Minolta Chroma-Meter colorimeter by taking 3 readings in each of the 3 fruits of each repetition, which were expressed in the $\mathrm{L}^{*}, \mathrm{a}^{*}$ and $\mathrm{b}^{*}$ colorimetric system, according to the CIE Color System 1976 allowing the characterization of color through the color angle or Hue angle $\left(\mathrm{h}^{\circ}\right)$ parameters, which is determined by the equation $\tan ^{-1}\left(\mathrm{~b}^{\star} / \mathrm{a}^{\star}\right)$. The apparatus was calibrated with illuminant $\mathrm{D} 65,10^{\circ}$ aperture, daylight equivalent, and regular transmission reading mode; it was calibrated to a white porcelain reference plate (C6299 Hunter Color Standard) (MINOLTA CORP., 1994).

\section{Firmness}

Firmness was determined using a digital penetrometer (TA - XT2 $\mathrm{i}^{\oplus}$ texture analyzer) with a $3 \mathrm{~mm}$ diameter flat tip by taking three equidistant readings in the equatorial region of the 3 fruits of each repetition. The results were expressed in Newton $(\mathrm{N})$.

\subsection{Physiochemical and chemical analyses}

\section{Total soluble solids (TSS)}

The endocarp of the 12 fruits used in the physical analyses (4 repetitions of 3 fruits each) was removed, and their pulp was cut in pieces of approximately $1 \mathrm{~cm}^{3}$ and mixed together. A total of $10 \mathrm{~g}$ of pulp pieces were homogenized using a mechanical type polytron homogenizer, with $40 \mathrm{~mL}$ of water, and filtered in filter paper. The total soluble solids were determined by the addition 
of 2 drops of the filtrate in a Brix $0-45 \%$ digital refractometer (model REF 121) with automatic temperature compensation at $25^{\circ} \mathrm{C}$. The results were expressed in percentage (\%), according to AOAC (ASSOCIATION..., 2002).

\section{Total titratable acidity (TTA)}

Total titratable acidity was determined in duplicate by homogenizing $10 \mathrm{~g}$ mass of pulp as previously described. Three drops of $1 \%$ phenolphthalein and titrated with a $\mathrm{NaOH} 0,1 \mathrm{~N}$ solution, previously standardized, was added to the filtrate used in the determination of TSS until the indicator reached the turning point. The results were calculated and expressed in percentage (\%) of citric acid (INSTITUTO..., 1985).

\section{Ethylene}

A parallel experiment was conducted to quantify the ethylene synthesis of guavas cv. Pedro Sato during ripening at room temperature.

Sixteen harvested guavas were weighed and disinfected as previously described. They were selected, placed in 8 uncovered glass containers of known volume (1.7 L) (2 fruits per container), and stored on the shelf together with the fruits used in the physical and physiochemical analyses for a 9-day ripening period (the first ethylene analysis was conducted 24 hours after harvest). For the quantification of the ethylene produced by the 2 guava fruits of known mass, every day of ripening, the containers were covered tightly and after a period of 1 hour their atmosphere was collected using a $10 \mathrm{~mL}$ vaccum tube for a period of 1 minute. A $0.5 \mathrm{~mL}$ aliquot of that atmosphere was injected into a gas chromatograph (Shimadzu GC-14B) equipped with flame ionization detector under the following conditions: PorapaK Q packed column; injector temperature $250{ }^{\circ} \mathrm{C}$; detector temperature $280{ }^{\circ} \mathrm{C}$; and initial column program temperature $90{ }^{\circ} \mathrm{C}$ (the temperature of the column was increased after 4.5 minutes at a rate of $100{ }^{\circ} \mathrm{C}$ per minute until reaching $220^{\circ} \mathrm{C}$ to clean the column); nitrogen carrier gas, and column flow and pressure $20 \mathrm{~mL} /$ minute and $0.1 \mathrm{psi}$, respectively. The area of the ethylene peak was compared with the area of peaks obtained from standards of known concentrations, and the ethylene concentration was calculated. The results were expressed in $\mu \mathrm{L}$ ethylene produced by kilogram of guava per hour of ripening ( $\mu \mathrm{L} \cdot \mathrm{kg}^{-1} /$ hours).

The experimental design used was completely random (CRD) with 8 treatments (1-8 days of ripening). The experimental procedure consisted of 2 flasks with 2 fruits each with 4 repetitions totaling 8 flasks and 16 fruits.

Ethylene quantification in each treatment was carried out with 2 daily collections (early in the morning and end of the afternoon) per flask, totaling 4 collections per repetition.

\section{Results and discussion}

Ethylene production of guava cv. Pedro Sato during ripening at room temperature is shown in Figure 1. The ethylene synthesis in the first 4 days of ripening was practically constant (approximately $0.1 \mu \mathrm{L}$ of ethylene. $\mathrm{kg}^{-1} /$ hours) and henceforth

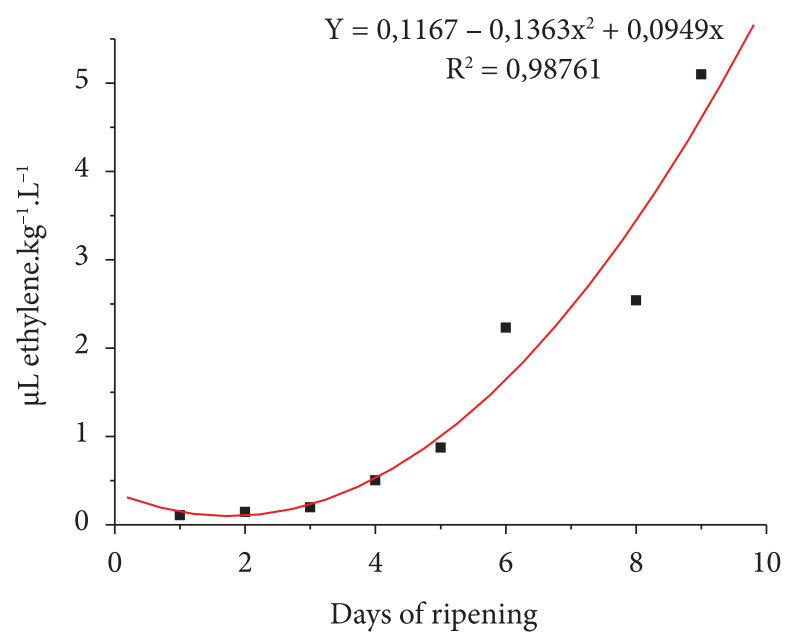

Figure 1. Ethylene production of guava cv. Pedro Sato during nine days of storage under ambient conditions.

started to increase until reaching $5 \mu \mathrm{L} \cdot \mathrm{kg}^{-1} /$ hours approximately on the $8^{\text {th }}$ day of ripening.

The results obtained are in agreement with those found by Akamine and Goo (1979), Mattiuz (2002) and Azzolini (2005), in relation to the cv. Pedro Sato; however, there are some differences between these studies. For Lima, Durigan and Tostes (1998), when picked at the half-ripe stage, guava presents a peak of respiration three days after harvest, while for Mattiuz (2002), when picked at the half ripe stage and stored at room temperature, it presents a constant increase in the respiration activity up to seven days after harvest, a period in which the fruits presented a high degree of senescence.

According to Abeles, Morgan and Saltveit (1992), ethylene is physiologically active at very low concentrations and sufficient to promote physiological responses. If guava is capable of responding at that low amount of ethylene, even though the sensitivity of tissue to ethylene depends on the tissue and its development stage, the amount of that hormone on the harvest day is already enough to provoke the ripening process. The accentuated increase starting from the fourth day of ripening should be associated to other physiological activities different from those usually associated to the quality and flavor of fruits such as color, texture, total soluble solids, and the total titratable acidity. Since the ethylene peak occurs at a very advanced ripening stage, after the $9^{\text {th }}$ day in the present study, when the fruit can no longer be consumed in natura, it can be suggested that the ethylene synthesis is associated to other factors such as the production of volatile compounds that can be attractive to insects and birds in order to promote the decomposition of the fruit and the spread of its seeds for propagation of the species.

The hue angle color $\left(\mathrm{h}^{\circ}\right)$ is a measurement in which a value of $0^{\circ}$ is attributed to the red color, $90^{\circ}$ to yellow, $180^{\circ}$ to green, and $270^{\circ}$ to blue. The values of the hue angle color $\left(\mathrm{h}^{\circ}\right)$ of the pulp and peel of guavas cv. Pedro Sato obtained during eight days of storage under ambient conditions are presented in Figures 2 and 3 . The values of hue angle $\left(h^{\circ}\right)$ decreased with the ripening 
progress following a quadratic equation indicating a fading of the green color and revealing of the yellow color, characteristic of climateric fruit ripening. The same behavior was observed for the color of the pulp with a decrease in the corresponding $\mathrm{h}^{\circ}$ angle with a color shift from pink to intense red.

The peel and pulp color fading apparently does not depend on the ethylene production because in the first 4 days the fading of peel and pulp color was intense although the ethylene synthesis was still practically constant.

The $\mathrm{h}^{\circ}$ angle values coincide with the results found by Mendonça et al. (2007), Bassetto et al. (2005) and MercadoSilva et al. (1998).

Fruit color is the most commonly used criterion by consumers in deciding whether to buy a fruit, as well as seeddispersing animals.

Peel color changes result from a decrease in the chlorophyll concentration and an increase in the carotenoid concentration, while pulp color changes are probably due to an increase in

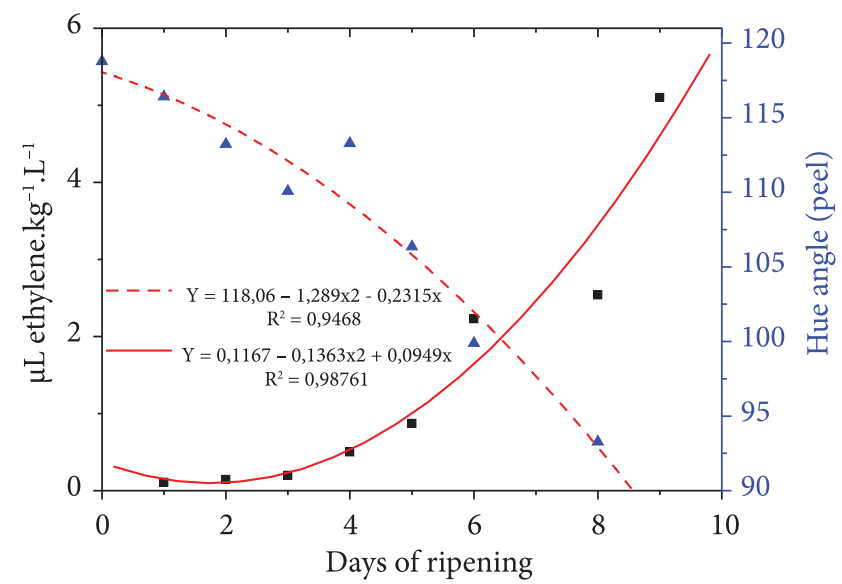

Figure 2. Curves and regression equations representing the values of peel hue ( $\mathbf{\Delta}$ ) and ethylene ( $\mathbf{*}$ ) of guavas $\mathrm{cv}$. Pedro Sato during eight days of storage under ambient conditions.

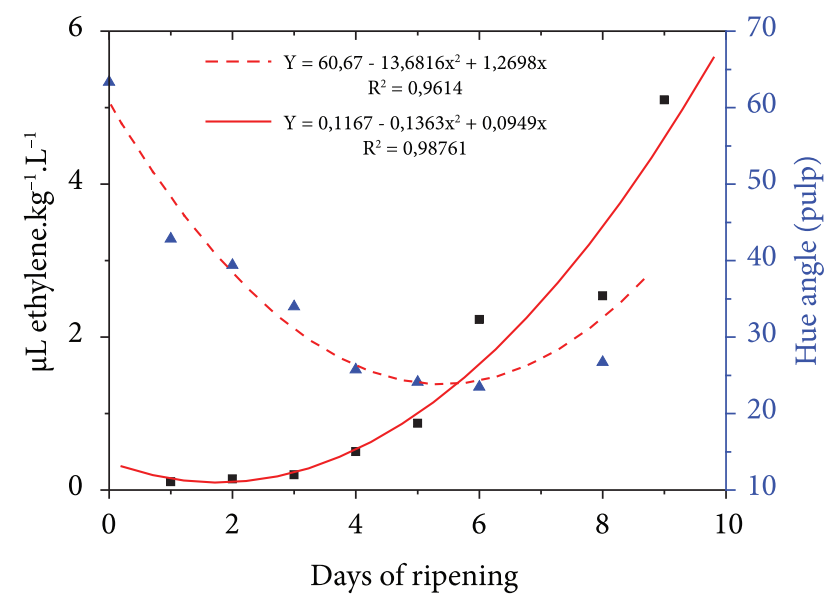

Figure 3. Curves and regression equations representing the values of pulp hue ( $\mathbf{\Delta}$ ) and ethylene ( $\bullet$ ) of guavas cv. Pedro Sato during eight days of storage under ambient conditions. the lycopene biosynthesis (ADSULE; KADAM, 1995; KAYS; PAULL, 2004).

The fruit softening or loss of firmness, after the color change, is the most important change that occurs in the ripening process (AWAD, 1993; OLIVEIRA et al., 2006).

The decrease in the firmness of guava cv. Pedro Sato during ripening at room temperature is better explained by a quadratic equation (Figure 4) indicating that on the harvest day (half ripe fruits light green peel) the firmness was $11 \mathrm{~N}$, and it decreased sharply until the $4^{\text {th }}$ day of ripening ( $3 \mathrm{~N}$; reduction of $73 \%$ ), when the fruits were already soft.

The studies that have analyzed the firmness of guavas $\mathrm{cv}$. Pedro Sato during the ripening at room temperature presented similar results (LIMA, 2004; XISTO et al., 2004). However, some of the results presented in the literature for other guava cultivars have shown similar results with variation of $75 \%$, guavas 'Cortibel 1' and 'Cortibel 4' (MENDONÇA et al., 2007), $83 \%$ in guavas cv. Allahabad Safeda (SING; PAL, 2008) and other quite different results, with firmness variations of $34 \%$ between the $3^{\text {rd }}$ and $7^{\text {th }}$ day of ripening for $\mathrm{cv}$. Média China (MERCADO-SILVA et al., 1998), while the cv. Kumagai showed variations of only $25 \%$ between the $1^{\text {st }}$ and $10^{\text {th }}$ day of ripening (CARVALHO et al., 2001b). It should be pointed out that this cultivar is considered as a long shelf life cultivar.

The firmness of green and ripe fruits is mainly due to pectin polymers, which can be methylated with varied degrees of methylation (KERTESZ, 1951; FERTONANI, 2006), can be bonded to ions, mainly $\mathrm{Ca}^{++}$, which maintains adjacent chains bonded among themselves, or can even present their glycosidic chains interconnected among themselves by phenolic compounds (TAIZ; ZEIGER, 2004).

The loss of firmness during the ripening of fruits is due to hydrolytic enzyme activity that promotes intense solubilization of the pectins present in the cell wall, mainly pectinmethylesterase (PME) and polygalacturonases (PG) (TUCKER, 1993; JAIN et al., 2001; OLIVEIRA, et al., 2006). Considering that guava $\mathrm{cv}$. Pedro Sato does not present

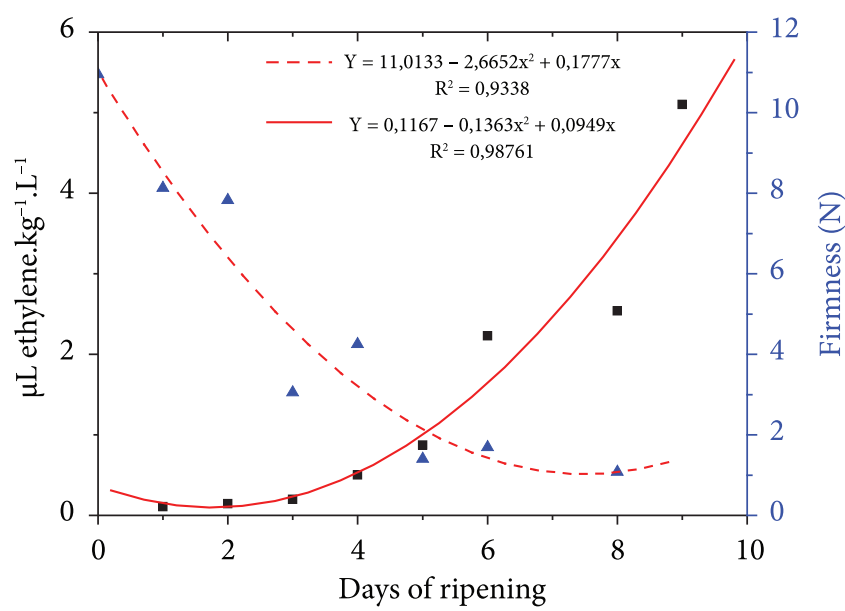

Figure 4. Variation of firmness ( $\mathbf{\Delta}$ ) and ethylene ( $\bullet$ ) of guavas cv. Pedro Sato during storage under ambient conditions. 
polygalacturonase activity (LINHARES et al., 2007), the rapid decrease in firmness, remains inexplicable. The existence of high esterase activity in the cell membrane/cell wall of guava kernel (LINHARES et al., 2007) suggests that the rapid decrease in firmness occurs by processes other than the polygalacturonic acid hydrolysis.

It should also be pointed out that the rapid decrease in firmness is not related to the ethylene synthesis since until the $4^{\text {th }}$ day of ripening, when there was reduction of $73 \%$, the amount of ethylene remained very low and constant (Figure 4). It is still not clear whether the amount of ethylene in the guava fruit on the first days of ripening is already enough to cause all changes in firmness, as reported by Abeles, Morgan and Saltveit (1992).

The total soluble solids (TSS) did not vary with the ripening of the guavas cv. Pedro Sato, and they presented an average of $7.6^{\circ} \mathrm{Brix}$ (Figure 5), which is in accordance with the results found by Jacomino (1999) and Xisto (2002). However, Brix levels between 4.8 and 15.9 Brix have been mentioned in the literature (PAIVA, 1994; MOHAMED; KYI; YUSOF, 1994; CHITARRA, 1996; GERHARDT et al., 1997; MERCADOSILVA et al., 1998; LIMA et al., 1999; MENDONÇA et al., 2007) depending, however, on the variety, climatic conditions, and maturation stage.

The behavior of the TSS during the ripening of climateric fruits consists of a very significant increase, resulting mainly from the conversion of starch into simple sugars such as the glucose, fructose, and sucrose, thus causing changes in the flavor (increasing sweetness) (ESTEVES; CARVALHO, 1982; CHITARRA; CHITARRA, 2005).

The increase in the TSS in these fruits is always associated to an ethylene synthesis increase. Since during the ripening of guava cv. Pedro Sato there was no variation in the level of TSS, but the ethylene level increased starting from the $4^{\text {th }}$ day of ripening, it is believed that guava, is not a climateric fruit.

The total titratable acidity (TTA) and TSS did not change during the ripening of guavas $\mathrm{cv}$. Pedro Sato either, presenting an average level of 0.5 citric acid equivalents per $100 \mathrm{~g}$ of pulp (Figure 6), the same value found by Azzolini (2002) for that cultivar at different ripening stages. Although they did not find variation in the TTA, Gerhardt et al. (1997) mentioned that it can vary from 0.24 to $1.79 \mathrm{mg}$ citric acid per $100 \mathrm{~g}$ of pulp depending on other factors such as variety and the climatic conditions.

In climateric fruits, the TTA usually decreases during ripening due the use of the organic acids, besides sugars, as a respiration substrate (CHITARRA; CHITARRA, 2005). Such biological oxidation depends on ethylene production.

Through the analysis of characteristic, it is verified that guavas cv. Pedro Sato are not climateric fruits either.

The classification of fruits as climateric and non-climateric is a great simplification of the ripening process (ABDI et al., 1998). Examples of controversies regarding that classification have already been mentioned in the literature for peaches (ABDI et al., 1997), pears (DOWNS et al., 1991), and specially for guava, which was classified as both climateric (OLIVEIRA,

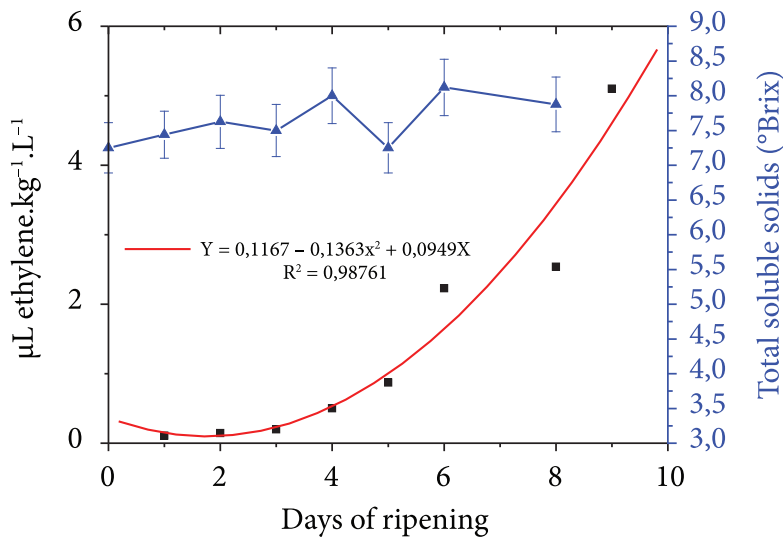

Figure 5. Average total soluble solid levels ( $\mathbf{\Delta}$ ), curve and regression equation representing ethylene values (-) of guavas cv. Pedro Sato during storage under ambient conditions.

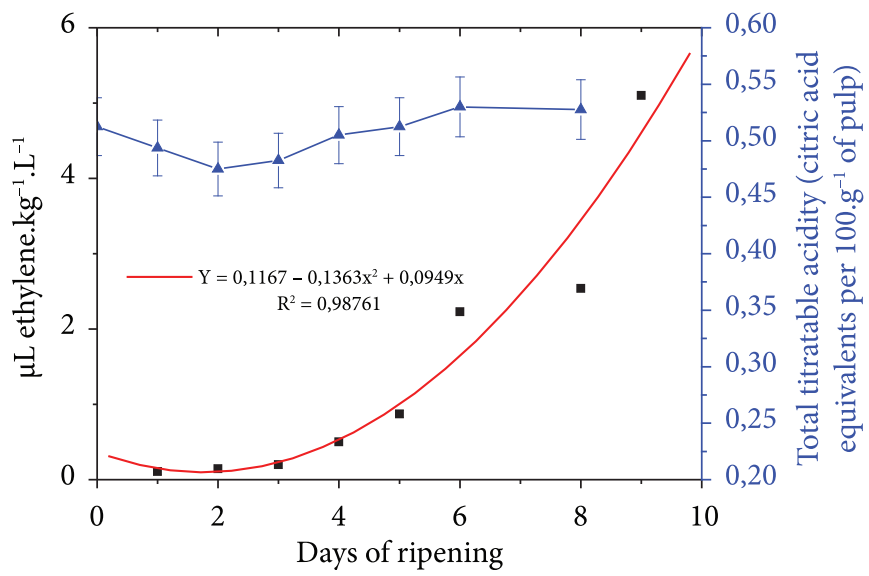

Figure 6. Total titratable acidity ( $\mathbf{\Delta})$ and ethylene production $(\mathbf{-})$ of guavas $\mathrm{cv}$. Pedro Sato during storage under ambient conditions.

1996; MERCADO-SILVA et al., 1998; LIMA; DURIGAN; TOSTES 1998; AZZOLINI, 2005; MENDONÇA et al., 2007) and non-climateric fruit (BIALE; BARCUS, 1970; MEDINA et al., 1998; CHITARRA; CHITARRA, 2005).

\section{Conclusions}

In the present study, the guava harvested at the half-ripe stage presented color changes and loss of firmness characteristic of climateric fruits and constant levels of TSS and TTA, characteristic of non-climateric fruits.

It is verified that the classification of the fruits as climateric or non-climateric only does not consider the physiological behavior that occurs in guavas, and that the proposal of a new class of classification that includes these behaviors becomes indispensable for certain species, variety, or cultivar.

\section{Acknowledgements}

The authors are grateful for the financial support provided by CAPES and to the Graduate program in Agrochemistry. 


\section{References}

ABELES, F. B.; MORGAN, P. W.; SALTVEIT, M. E. Ethylene in Plant Biology. San Diego: Academic Press, 1992. 414 p.

ABDI, N. et al. Responses of climateric and supressed-climacteric plums to treatment with propylene and 1- methylcyclopropene. Postharvest Biology and Technology, v. 14, p. 29-39, 1998. http://dx.doi.org/10.1016/S0925-5214(98)00031-3

ABDI, N. et al. Ripening behaviour and responses to proprylene in four cultivares of Japanese type plums. Postharvest Biology and Technology, v. 12, p. 21-34, 1997. http://dx.doi.org/10.1016/S09255214(97)00041-0

ADSULE, R. N.; KADAM, S. S. Guava. In: SALUNKHE, D. K.; KADAM, S. S. (Eds.). Handbook of fruit science and technology, production composition, storage and processing. New York: Marcel Dekker, 1995. cap. 9, p. 419-433.

AKAMINE, E. K.; GOO, T. Repiration and ethylene production in fruits of species and cultivars of Psidium and species of Eugenia. Journal of the American Society for Horticultural Science, v. 104, n. 5, p. 632-635, 1979.

ARCHBOLD, D. D.; POMPER, K. W. Ripening pawpaw fruit exhibit respiratory and ethylene climacterics. Postharvest Biology and Technology, v. 30, n. 1, p. 99-103, 2003. http://dx.doi.org/10.1016/ S0925-5214(03)00135-2

ASSOCIATION OF OFFICIAL ANALYTICAL CHEMISTRY - AOAC. Official methods of analysis of the Association of Official Analytical Chemistry. 12. ed. Washington, 2002. 11115 p.

AWAD, M. Fisiologia pós-colheita de frutos. São Paulo: Nobel, 1993. 114 p.

AZZOLINI, M. Ripening of "Pedro Sato" guava: study on its climacteric or non-climacteric nature. Brazilian Journal of Plant Physiology, v. 17, n. 3, 2005. http://dx.doi.org/10.1590/S167704202005000300004

AZZOLINI, M. Fisiologia pós-colheita de goiabas 'Pedro Sato': estádios de maturação e padrão respiratório. Piracicaba, 2002. 100 p.

BASSETTO, E.; JACOMINO, A. P.; PINHEIRO, A. L. Conservation of "Pedro Sato" guavas under treatment with 1-methylcyclopropene. Pesquisa Agropecuária Brasileira, v. 40, n. 5, p. 433-440, 2005. http://dx.doi.org/10.1590/S0100-204X2005000500002

BIALE, J. B.; BARCUS, D. E. Respiratory patterns in tropical fruits of the amazon Basin. Tropical Science, v. 12, p. 93-104, 1970.

BROWN, B. I.; WILLS, R. B. H. Post-harvest changes in guava fruit of diferente maturing. Scientia Horticulturae, v. 19, n. 3-4, p. 237-243, 1983. http://dx.doi.org/10.1016/0304-4238(83)90069-9

CARVALHO, H. A. et al. Efeito da atmosfera modificada sobre componentes da parede celular da goiaba. Ciência e Agrotecnologia, v. 25, n. 3, p. 605-615, 2001a.

CARVAlHO, H. A. et al. Eficiência da concentração de cloreto de cálcio e do tempo de imersão no tratamento pós-colheita de goiaba branca cv. Kumagai. Revista Brasileira de Fruticultura, v. 20, n. 3 , p. 375-381, 2001b.

Chitarra, M. I. F., Chitarra, A. B. Pós-colheita de frutas e hortaliças: fisiologia e manejo. 2. ed. Lavras: UFLA, 2005. 785 p.

CHITARRA, M. I. F. Características das frutas de exportação. In: GONGATTI NETO, A. et al. Goiaba para exportação: procedimentos de colheita e pós-colheita. Brasília: EMBRAPA, 1996. cap.1, p. 9- 11. (Série Publicações Técnicas FRUPEX, n. 20).
DOWNS, C. G. et al. Normal ripening cultivars of Pyrus serotina are either climateric or non- climateric. Science Horticulturae, v. 4, p. 125-130, 1991.

ESTEVES, M. T. C.; CARVALHO, V. D. Modificações nos teores de amido, açúcares e grau de doçura de frutos de seis cultivares de goiabeira (Psidium guajava L.) em diferentes estádios de maturação. Ciência e Prática, v. 6, n. 2, p. 208-218, 1982.

FERTONANI, H. C. R. Estabelecimento de um modelo de extração ácida de pectina de bagaço de maçã. 2006. 82 f. Dissertação (Mestrado em Ciência e Tecnologia de Alimentos)-Universidade Federal de Ponta Grossa, Ponta Grossa, 2006.

GERHARDT, L. B. A. et al. Características físico- químicas dos frutos de quatro cultivares e três clones de goiabeira em Porto Lucena, RS. Pesquisa Agropecuária Brasileira, v. 32, n. 2, p. 185-192, 1997.

INSTITUTO BRASILEIRO DE GEOGRAFIA E ESTATÍSTICA - IBGE. Produção Agrícola Municipal. Rio de Janeiro, 2008. Disponível em: $<$ http://www.sidra.ibge.gov.br>. Acesso em: 19 ago. 2009.

INSTITUTO ADOLFO LUTZ. Normas analíticas, métodos químicos e físicos para análise de alimentos. 3. ed. São Paulo: IAL, 1985. v. 1, p. 533.

JACOMINO, A. P. Conservação de goiabas 'Kumagai' em diferentes temperaturas e materiais de embalagem. 1999. 90 f. Tese (Doutorado em Fitotecnia)-Escola Superior de Agronomia "Luiz de Queiroz", Universidade Estadual de São Paulo, Piracicaba, 1999.

JAIN, N. et al. Compositional and enzymatic changes in guava (Psidium guajava L.) fruits during ripening. Acta Physiologiae Plantarum, v. 23, p. 357-362, 2001. http://dx.doi.org/10.1007/ s11738-001-0044-7

KAYS, S. J.; PAULL, R. E. Postharvest biology. Athens: Exon Press, 2004.

KERTESZ, Z. I. The pectic substances. New York: Interscience, 1951.

LIMA, A. V. Qualidade pós-colheita da goiaba "Pedro Sato" tratada com Ca 'Cl IND.2' e 1-MCP em condições ambiente. 2004. 67 f. Dissertação (Mestrado em Agronomia)-Universidade Federal de Lavras, Lavras, 2004.

LIMA, M. A. et al. Caracterização físico-química dos frutos de 19 genótipos de goiabeira, obtidos na FCAV-UNESP. Revista Brasileira de Fruticultura, v. 21, n. 3, p. 252-257, 1999.

LIMA, M. A.; DURIGAN, J. F.; TOSTES, D. R. D. Avaliação do comportamento respiratório de goiabas 'Pedro Sato' e a influência de diferentes embalagens na sua conservação sob refrigeração. In: CONGRESSO BRASILEIRO DE CIÊNCIA E TECNOLOGIA DE ALIMENTOS, 16., 1998, Rio de Janeiro. Anais... Rio de Janeiro: SBCTA, 1998. v. 3, p. 1980-1983.

LINHARES, L. A. et al. Transformações químicas, físicas e enzimáticas de goiabas "Pedro Sato" tratadas na pós-colheita com cloreto de cálcio e 1-metilciclopropeno e armazenadas sob refrigeração. Ciência e Agrotecnologia, v. 31, n. 3, p. 829-841, 2007. http://dx.doi.org/10.1590/S1413-70542007000300033

MATTIUZ, B. Fisiologia e qualidade pós colheita de goiabas. 2002. 118p. Tese (Doutorado em Produção Vegetal)Faculdade de Ciências Agrárias e Veterinárias, Universidade Estadual Paulista, Jaboticabal, 2002.

MEDINA, J. C. et al. Goiaba: cultura, matériaprima, processamento e aspectos econômicos. 2. ed. rev. ampl. Campinas: ITAL, 1998. 224 p. (Frutas Tropicais, n. 6).

MENDONÇA, R. D. et al. Caracteristicas físicas e químicas de goiabas 'cortibel 1' e 'cortibel 4' armazenadas em condições ambientais. Bragantia, v. 66, n. 4, p. 685-692, 2007. 
MERCADO-SILVA, E.; BAUTISTA, P. B.; GARCIA-VELASCO, M. A. Fruit development, harvest index ripening changes of guavas produced in central Mexico. Postharvest Biology and Technology, v. 13 , n. 2, p. 143-150, 1998. http://dx.doi.org/10.1016/S09255214(98)00003-9

MINOLTA CORP. Precise Color Communication. Ramsey: Minolta Corporation Instrument Systems Division, 1994. p. 45-49.

MOHAMED, S.; KYI, K. M. M.; YUSOF, S. Effects of various surface treatments on the storage life of guava (Psidium guajava L.) at $10^{\circ} \mathrm{C}$. Journal of Science of Food and Agriculture, v. 66, p. 9-11, 1994. http://dx.doi.org/10.1002/jsfa.2740660103

OLIVEIRA, A. C. G. et al. Conservação pós-colheita de goiaba branca kumagai por irradiação gama: aspectos físicos, químicos e sensoriais. Boletin CEPPA, v. 24, n. 2, p. 375-396, 2006.

OLIVEIRA, M. A. Utilização de película de mandioca como alternativa à cera comercial na conservação pós-colheita de frutos de goiaba (Psidium guajava). 1996. 73 f. Dissertação (Mestrado)Universidade de São Paulo, Piracicaba, 1996.

PAIVA, M. C. Competição entre quatro cultivares e três seleções de goiabeiras em eldorado do Sul, RS. Pesquisa Agropecuária Brasileira, v. 29, n. 6, p. 17-922, 1994.

RHODES, M. J. C. The maturation and ripening of fruits. In: THIMANN, K. V.; ADELMAN, R. C.; ROTH, G. S. Senescence in plants. Florida: CRC Press, 1980. cap. 8, p. 157-205.
SINGH, S. P.; PAL, R. K. Response of climacteric-type guava (Psidium guajava L.) to postharvest treatment with 1-MCP. Postharvest Biology and Technology, v. 47, p. 307-314, 2008. http://dx.doi. org/10.1016/j.postharvbio.2007.08.010

TAIZ, L.; ZEIGER, E. Fisiologia Vegetal. 3. ed. Porto Alegre: Artmed. 2004. 719 p.

TUCKER, G. A. Introduction. In: SEYMOUR, G. B.; TAYLOR, J. E.; TUCKER, G. A. Biochemestry of fruit ripening. London: Chapmal \& Hall, 1993. cap.1, p. 2-51.

XISTO, A. L. R. P. Conservação pós-colheita de goiaba "Pedro Sato" com aplicação de cloreto de cálcio em condições ambientais. 2002. 47 f. Dissertação (Mestrado)-Universidade Federal de Lavras, Lavras, 2002.

XISTO, A. L. R. P. et al. Textura de goiabas 'Pedro Sato' submetidas à aplicação de cloreto de cálcio. Ciência e Agrotecnologia, v. 28 , n. 1, p. 113-118, 2004. http://dx.doi.org/10.1590/S141370542004000100015

YAGI, M. I.; SALIH; O. M.; SALIH, S. M. Preliminary investigation on improving the quality of guava in the Sudan. Sudan Journal Food Science Technology, v. 9, p. 11-14, 1977.

ZONTA, E. P.; MACHADO, A. A. Manual do Saneste: Sistema de análise estatística para microcomputadores. Pelotas: UFPel, 1991. 102 p. 